\title{
Achyrocline satureioides (Lam.) DC extracts acting as enzyme modulators: digestion, inflammation, and hemostasis
}

\author{
Extratos de Achyrocline satureioides (Lam.) DC atuando como \\ moduladores enzimáticos: digestão, inflamação e hemostasia
}

\author{
Mariana Aparecida Braga ${ }^{1}$, Tatiane Silva de $\mathrm{Abreu}^{2}$, Marcus Vinícius \\ Trento $^{3}$, Pedro Henrique Cesar ${ }^{4}$, Tamara Rezende Marques ${ }^{4}$, \\ Sérgio Scherrer Thomasi ${ }^{5}$, Silvana Marcussi ${ }^{6}$
}

\begin{abstract}
Achyrocline satureioides is popularly known for its richness in phenolic compounds and medicinal properties (anti-inflammatory, analgesic, and hepatoprotective). The present study aimed at broadening the knowledge about the pharmacological potential exerted by the aqueous and ethanolic extracts of $A$. satureioides. These extracts were characterized by HPLC and tested for their modulatory action on phospholipases $\mathrm{A}_{2}$ and proteases of snake venoms. In addition, they were tested on the activities of digestive enzymes. Snake venoms were used as tools since they have enzymes with high functional and structural homology to human enzymes. The results demonstrate that the extracts of $A$. satureioides act as enzymatic inhibitors or potentiators, interfering in processes related to the hemostasis, such as coagulation and thrombus dissolution. In addition, the anti-genotoxic activity and inhibitions exerted on digestive enzymes suggests their potential use in the prevention and/or treatment of several pathologies. New studies could provide information on how the compounds present in the extracts and the different enzymes interact.
\end{abstract}

Keywords: Comet assay; Proteases inhibitors; Phospholipases inhibitors; Medicinal plants; Toxins as tools.

${ }^{1}$ Doutorado em Agroquímica (Química/Bioquímica) pela Universidade Federal de Lavras (UFLA), Lavras, Minas Gerais, Brasil.E-mail: marybraga07@yahoo.com.br

${ }^{2}$ Doutorado em Agroquímica (Química/Bioquímica) pela Universidade Federal de Lavras, Lavras, Minas Gerais, Brasil. Professora Substituta de Química no Instituto Federal do Sul de Minas Gerais (IFSULDEMINAS), Inconfidentes, Minas Gerais, Brasil.

${ }^{3}$ Doutorando em Agroquímica (Química/Bioquímica) na Universidade Federal de Lavras, Lavras, Minas Gerais, Brasil.

${ }^{4}$ Doutorado em Agroquímica (Química/Bioquímica) pela Universidade Federal de Lavras, Lavras, Minas Gerais, Brasil.

${ }^{5}$ Doutorado em Química pela Universidade Federal de São Carlos (UFSCar), São Carlos, São Paulo, Brasil. Professor Adjunto do Departamento de Química da Universidade Federal de Lavras, Lavras, Minas Gerais, Brasil.

${ }^{6}$ Doutorado em Bioquímica pela Universidade de São Paulo (USP), São Paulo, São Paulo, Brasil. Professora Associada IV do Departamento de Química da Universidade Federal de Lavras, Lavras, Minas Gerais, Brasil. 


\section{Resumo}

A Achyrocline satureioides é popularmente conhecida por sua riqueza em compostos fenólicos e por suas propriedades medicinais (anti-inflamatória, analgésica e hepatoprotetora). No presente estudo, com o objetivo de ampliar o conhecimento sobre o potencial farmacológico exercido por esses extratos, os extratos aquoso e etanólico de $A$. satureioides foram caracterizados por HPLC e testados quanto à sua ação modulatória sobre as fosfolipases $A_{2}$ e proteases de peçonhas de serpentes. Além disso, também foram testados em atividades de enzimas digestivas. As peçonhas de serpentes foram usadas como ferramentas por apresentarem enzimas com alta homologia funcional e estrutural às humanas. Os resultados demonstram que os extratos de A. satureioides atuam como inibidores ou potencializadores enzimáticos, interferindo em processos relacionados à hemostasia, como coagulação e dissolução do trombo. Além do mais, destacam seu potencial antigenotóxico e as inibições exercidas sobre as enzimas digestivas direcionando seu potencial de uso na prevenção e/ou tratamento de diversas patologias. Novos estudos poderão fornecer informações sobre os mecanismos de interação entre os compostos presentes nos extratos e as diferentes enzimas.

Palavras-chave: Ensaio cometa; Inibidores de proteases; Inibidores de fosfolipases; Plantas medicinais; Toxinas como ferramentas.

\section{Introduction}

Bioactive compounds extracted from plants have been investigated for their pharmacological properties, primarily aiming at therapeutic applications in the prevention and treatment of several diseases. Several are the mechanisms by which these compounds exert their effects. Among them, the antioxidant, anti-inflammatory, enzyme-inhibiting, and protective actions on the genetic material stand out. Although the compounds present in medicinal plants have many beneficial effects on human health, they may induce toxic and genotoxic effects in some situations..$^{(1-2)}$

Snake venoms are mainly composed of enzymes such as phospholipases $\mathrm{A}_{2}$, metalloproteases, and serine proteases. They affect vital physiological functions by altering the hemostasis and the inflammatory and immune responses. ${ }^{(3)}$ In addition, many of these enzymes have a high degree of structural and functional homology with the ones present in the human organism, thus allowing their use as tools to simulate possible interactions of natural compounds with different enzymes.

Achyrocline satureioides (Lam.) DC (family Asteraceae), often known as 'marcela' or 'macela,' is commonly used in Brazil's folk medicine as tea to cure digestive and inflammatory issues. A. satureioides extracts have anti-inflammatory, analgesic, and sedative properties, and are also suggested for the treatment of gastrointestinal dysfunctions due to their hepatoprotective and antispasmodic properties. ${ }^{(4)}$

In order to increase this knowledge, the effects of its extracts on hemostasis and enzymatic activities were evaluated. Thus, a toxic-pharmacological characterization of the aqueous and ethanolic extracts from leaves of $A$. satureioides was carried out in the present work.

\section{Material and Methods}

\section{Sample collection and preparation of aqueous and ethanolic extracts}

Dry leaves of $A$. satureioides (Lam.) DC were purchased at a local shop in Lavras city, Minas Gerais state, Brazil $\left(21^{\circ} 14^{\prime} \mathrm{S}, 45^{\circ} 00^{\prime} \mathrm{W}\right.$, and $918 \mathrm{~m}$ altitude) in April 2018 (lot number 1511122293). The leaves were milled in a Wiley mill, and the obtained flour was used to prepare the extracts in two different solvents: water (30 minutes infusion in ratio 1:25; w:v; freshly boiled water) and 70\% ethanol (at room temperature by static maceration 
during 15 days). The extracts were filtered, and the supernatants were collected. The aqueous extract was frozen and then lyophilized. The hydroalcoholic extract was subjected to removal of the solvent on a rotary evaporator $\left(\right.$ at $45^{\circ} \mathrm{C}$ ), then frozen and lyophilized. The lyophilized extracts were solubilized in phosphate-buffered saline (PBS) to be used in the experiments. This study received the authorization to access the genetic patrimony (Conselho de Gestão do Patrimônio Genético - CGen, Brazil) under the process number A5D79A6.

Phytochemical screening and determination of the extract's phenolic composition by HPLC

The aqueous and ethanolic extracts of $A$. satureioides (Lam.) DC leaves were submitted to phytochemical screening, using specific reagents for each chemical group and chemical reactions that resulted in coloration and/or precipitation characteristic for each class of substances. ${ }^{(5)}$ Organic acids, alkaloids, azulenes, carotenoids, catechins, depsides and depsidones, coumarin derivatives, steroids and triterpenoids, flavonoids, cardiac glycosides, sesquiterpene lactones and other lactones, saponins, purines, and tannins were investigated.

Chromatographic analysis was performed using a Shimadzu high-performance liquid chromatography (HPLC) system, equipped with two LC-20AT high-pressure pumps, a UV-visible detector model SPD-M20A, oven model CTO-20AC, an interface model CBM-20A, and an automatic injector with auto-sampler model SIL-20A. Separations were performed using a Shim-pack VPODS-C18 (250 mm x $4.6 \mathrm{~mm})$ column connected to a Shim-pack Column Holder (10 mm x $4.6 \mathrm{~mm}$ ) pre-column.

The lyophilized extracts, dissolved in water $(1: 20, w: v)$, and the phenolic standards were filtrated in a $0.45 \mu \mathrm{m}$ membrane (Millipore ${ }^{\circledR}$ ) and injected into the chromatograph. The analyses were carried out according to Marques et al. ${ }^{(6)}$
The mobile phase consisted of solutions of $2 \%$ acetic acid in water (A) and methanol:water:acetic acid (70: 28: 2, v/v/v) (B). The analyses were performed in 65 minutes at $40{ }^{\circ} \mathrm{C}$, with a flow rate of $1.0 \mathrm{~mL} / \mathrm{min}$, wavelength of $280 \mathrm{~nm}$, and an injection volume of $20 \mu \mathrm{L}$ in gradient elution (starting at $100 \%$ of solvent $\mathrm{A}$ up to $5 \mathrm{~min} ; 70 \%$ of solvent A from 5 to $25 \mathrm{~min} ; 60 \%$ of solvent A from 25 to $43 \mathrm{~min}$; $55 \%$ of solvent A from 43 to $50 \mathrm{~min}$; and $0 \%$ of solvent A for $10 \mathrm{~min}){ }^{(6)}$ The standards used were: ferulic acid, salicylic acid, syringic acid, gallic acid, p-coumaric acid, epicatechin, catechin, epicatechin gallate, resveratrol, and quercetin.

\section{Snake venoms}

The crystallized crude venoms were purchased from the serpentarium Bioagents (Batatais city, São Paulo state, Brazil). To perform the assays, the venoms were weighed and dissolved in phosphate-buffered saline (PBS, pH 7.4).

The venoms were previously evaluated in all the tests to define the minimum doses that induce the activities. This study received the authorization to access the genetic patrimony (CGen, Brazil) under the process numbers ABA4AB3 and ADF95EA.

\section{Obtaining human blood}

The blood used for the hemolytic, thrombolytic, and coagulation activities and the comet assay were obtained from healthy volunteers. All tests were carried out with the prior authorization of the Ethics Committee on Human Research (COEP) of the Universidade Federal de Lavras (UFLA), in Lavras, Minas Gerais, Brazil, under the registration number: CAAE: 56628316.0.0000.5148.

\section{Phospholipase and hemolytic activity}

The phospholipase and hemolytic activities were evaluated in a solid medium as described by 
Gutiérrez et al. ${ }^{(7)}$ The gel for the evaluation of the phospholipase activity was prepared with $0.01 \mathrm{~mol}$ $\mathrm{L}^{-1} \mathrm{CaCl}_{2}$; egg yolk lecithins 1:3 (v:v); phosphatebuffered saline (PBS), $\mathrm{pH} 7.4 ; 1 \%$ bacteriological agar; and $0.005 \%$ sodium azide, with the medium being poured at $45-50{ }^{\circ} \mathrm{C}$ into Petri dishes. After gel solidification, treatments were applied in small holes made in the gel, and the plates were maintained in a cell culture chamber for 12 hours at $37{ }^{\circ} \mathrm{C}$.

Phospholipase $\mathrm{A}_{2}$ assays were performed using the venoms of Bothrops atrox, B. jararacussu, and $B$. moojeni $(30 \mu \mathrm{g})$. Each venom was preincubated with the aqueous or ethanolic extracts for 30 minutes at $37^{\circ} \mathrm{C}$ in the ratios of 1:0.1, 1:0.5, 1:1, $1: 2.5,1: 5,1: 10$, and 1:20 (venom:extract, w:w).

For the hemolytic activity, the gel was prepared by replacing egg yolk lecithins with erythrocytes at a hematocrit concentration of $1 \%$. Inhibition of the hemolytic activity was evaluated using B. jararacussu, B. moojeni, and Crotalus durissus terrificus venoms $(50 \mu \mathrm{g})$ preincubated with the extracts in the ratios of $1: 0.05,1: 0.1 ; 1: 0.5 ; 1: 1$, $1: 2.5$, and $1: 5(\mathrm{w}: \mathrm{w})$. The diameter of the translucent halo around the hole in the gel was measured, and the results were converted in percentage (\%). The controls containing only venoms were considered as $100 \%$ of activity.

In both assays, previous controls were performed using only the extracts, and no activity was observed.

\section{Thrombolytic activity}

The thrombolytic activity was assessed on human blood clots formed in vitro according to the methodology described by Cintra et al. ${ }^{(8)}$ The clots were incubated for 24 hours at $37^{\circ} \mathrm{C}$ with samples containing B. moojeni and Lachesis muta muta (40 $\mu \mathrm{g}$ ), PBS, or venom previously incubated (30 minutes at $37^{\circ} \mathrm{C}$ ) with extracts of $A$. satureioides in the ratios of 1:0.5, 1:1, 1:2.5, and 1:5 (venom:extract, w:w). The activities were estimated by measuring the volume of fluid released by each thrombus. Controls containing only venoms were considered as $100 \%$ of activity.

\section{Coagulant activity}

To evaluate the effects of $A$. satureioides extracts on the venom-induced coagulation, the extracts were preincubated with $B$. moojeni and $L$. muta muta venoms for 10 minutes at $37{ }^{\circ} \mathrm{C}$ in the ratios of 1:0.5, 1:1, 1:2.5, 1:5, and 1:10 (venom: extract, w:w). Then, the incubated samples were added to the citrated human plasma $\left(200 \mu \mathrm{L} ; 37^{\circ} \mathrm{C}\right.$ in a water bath) and timed until clot formation. The minimum coagulant dose for each venom was previously defined as the smaller amount of venom capable of inducing coagulation in a range between 70 and 100 seconds. ${ }^{(9)}$ Controls containing B. moojeni, L. muta muta or the extracts were performed.

The results that are different from the controls in values equal to or greater than 10 seconds were considered significant. This is enough time to trigger the activation of prothrombin, which is approximately 10 to 14 seconds according to coagulation tests.

\section{Comet assay}

The comet assay was used to detect damage to DNA molecules of leukocytes. The treatments containing L. muta muta venom $(50 \mu \mathrm{g}$ in $300 \mu \mathrm{L}$ of PBS) were previously incubated with the extracts of $A$. satureioides in the ratios of $1: 0.5$ and $1: 1$ (venom:extract; w:w) for 30 minutes at $37^{\circ} \mathrm{C}$. The treatments were then added to $300 \mu \mathrm{L}$ of blood and kept in a cell culture chamber for 4 hours at $37^{\circ} \mathrm{C}$. $75 \mu \mathrm{L}$ aliquots were transferred to tubes containing $225 \mu \mathrm{L}$ of LMP agarose (low melting point). Three slides were prepared per treatment, $100 \mu \mathrm{L}$ per slide, as described by Nandhakumar et al. ${ }^{(10)}$ 
The slides were submitted to osmotic lysis following with electrophoresis run at $30 \mathrm{~V}$ and $300 \mathrm{~mA}$ for 30 minutes. After that, the nucleoids remained in a neutralization solution (0.4 M Tris- $\mathrm{HCl}, \mathrm{pH} 7.4)$ for 25 minutes. The slides were fixed with ethanol and visualized after staining with propidium iodide under epifluorescence microscopy. The analysis of nucleotide fragmentation levels was performed according to classes described by Collins et al., ${ }^{(11)}$ with some adaptations: class 0 , damages $\leq 5 \%$; class 1 , damages between 5 and $20 \%$; class 2, damages between 20 and $40 \%$; class 3 , damages between 40 and $85 \%$; and class 4 , damages $\geq 85 \%$.

Kinetic tests with digestive enzymes: with or without simulated gastric fluid

Obtaining enzymes

The following enzymes were used in these assays: porcine pancreatic lipase (EC 3.1.1.3) type II, Sigma; porcine pancreatic $\alpha$-amylase (EC 3.2.1.1) type VI B, Sigma; and porcine pancreatic trypsin (EC 3.4.21.4), Merck. The $\alpha$-glycosidase (EC 3.2.1.20) was obtained from fresh porcine duodenum according to Simão et al. ${ }^{(12)}$ The aqueous and ethanolic extracts of $A$. satureioides were prepared at the concentration of $25 \mathrm{~g} \mathrm{~L}^{-1}$.

$\alpha$-Amylase activity

The $\alpha$-amylase activity was determined according to Braga et al. ${ }^{(13)}$ The extracts were preincubated with $\alpha$-amylase enzyme for 20 minutes in a water bath at $37^{\circ} \mathrm{C}$. The substrate was $1 \%$ starch, prepared in $0.05 \mathrm{~mol} \mathrm{~L}^{-1}$ Tris buffer, $\mathrm{pH} 7.0$, with 38 mmol L-1 $\mathrm{NaCl}$ and $0.1 \mathrm{mmol} \mathrm{L}^{-1} \mathrm{CaCl}_{2}$. After that, $100 \mu \mathrm{L}$ of the substrate was added, and the mixture was incubated for four different periods $(10,20$, 30 , and 40 minutes). The reaction was interrupted with the addition of 3,5-dinitrosalicylic acid, and the product was measured in a spectrophotometer at the wavelength of $540 \mathrm{~nm}$.

\section{$\alpha$-Glycosidase activity}

The $\alpha$-glycosidase activity was determined according to Braga et al., ${ }^{(13)}$ using $5 \mathrm{mmol} \mathrm{L}^{-1}$ $p$-nitrophenyl- $\alpha$-D-glucopyranoside in a $0.1 \mathrm{~mol}$ $\mathrm{L}^{-1}$ citrate-phosphate buffer, $\mathrm{pH}$ 7.0, as substrate. The extracts and the $\alpha$-glycosidase enzyme were incubated at $37{ }^{\circ} \mathrm{C}$ for four different periods (10, 20, 30, and 40 minutes). Only then the substrate was added. The reaction was interrupted, and the product ( $p$-nitrophenol) was measured in a spectrophotometer $(410 \mathrm{~nm})$.

\section{Lipase activity}

The lipase activity was determined according to Souza et al..$^{(14)}$ and Braga et al. ${ }^{(13)}$ using 8 mmol L-1 $p$-nitrophenyl palmitate in a $0.05 \mathrm{mmol}$ $\mathrm{L}^{-1}$ Tris-HCl buffer, $\mathrm{pH} 8.0$, containing $0.5 \%$ Triton $\mathrm{X}-100$, as substrate. In the assay, the extracts and the lipase enzyme were incubated at $37{ }^{\circ} \mathrm{C}$ for four different periods (10, 20, 30, and 40 minutes). After the incubation, the substrate was added. The reaction was stopped by transferring the tubes to an ice bath and adding $0.05 \mathrm{mmol} \mathrm{L}^{-1}$ Tris-HCl buffer, $\mathrm{pH}$ 8.0. The $p$-nitrophenol was measured in a spectrophotometer $(410 \mathrm{~nm})$.

\section{Trypsin activity}

The trypsin activity was determined according to the methodology described by Braga et al. ${ }^{(13)}$ Thus, the aqueous and ethanolic extracts and the trypsin were incubated in a water bath at $37^{\circ} \mathrm{C}$, for different periods (10, 20, 30, and 40 minutes). Only then, the $p$-benzoyl-D-L-arginine-p-nitroanilide (BApNA) substrate was added (prepared in 0.05 mol L ${ }^{-1}$ Tris, $\mathrm{pH} 8.2$ ). The reaction was interrupted by adding $200 \mu \mathrm{L}$ of $30 \%$ acetic acid, and the 
product was measured in a spectrophotometer at a wavelength of $410 \mathrm{~nm}$.

\section{Preparation of simulated gastric fluid}

In the presence of a simulated gastric fluid, in vitro enzymatic activities were also carried out. The extracts were incubated with the simulated gastric fluid prepared according to The United States and Pharmacopeia ${ }^{(15)}$ for 1 hour at $37{ }^{\circ} \mathrm{C}$. Subsequently, they were neutralized $(\mathrm{pH}$ 7.2) with sodium bicarbonate salt.

Data analysis

To obtain 40 to $80 \%$ of enzyme inhibition on each enzymatic activity assay, the concentrations and dilutions of the aqueous and ethanolic extracts were different.

The enzymes inhibition were obtained from the determination of the slopes of the straight lines (absorbance $\mathrm{x}$ time) corresponding to values obtained for the control enzyme (without extracts) and enzymes + inhibitor (with aqueous or ethanolic extracts) in the activity assays. The slope of the straight line corresponds to the speed of product formation per minute of reaction. The absorbance values were converted into micromoles of product based on data obtained from a standard curve elaborated with glucose for the amylase and with $p$ nitrophenol for glycosidase and lipase. For trypsin, the molar extinction coefficient of BApNA was determined. ${ }^{(13)}$

\section{Statistical analysis}

The results were presented as the mean of the triplicates \pm standard deviation obtained in three independent assays. The significance of the means was determined by analysis of variance, followed by Tukey's test when the treatments were compared with the controls. ${ }^{(16)}$ The results were considered statistically significant when $\mathrm{p}<0.05$.

\section{Results and Discussion}

The phytochemical analysis of $A$. satureioides carried out in other works showed that this plant is rich in flavonoids. ${ }^{(17-18)}$ The results of the phytochemical screening showed the presence of metabolites in the ethanolic extract of $A$. satureioides that have pharmacological interest, such as catechins, flavonoids, coumarins, alkaloids, and saponins. On the other hand, only flavonoids, depsides, and depsidones were detected in the aqueous extract (Table 1).

The contents of phenolic compounds in the aqueous and ethanolic extracts, obtained by HPLC analysis, are also shown in Table 1 . The aqueous extract presented higher phenolic contents than the ethanolic extract but had a different chemical composition (absence of chlorogenic acid, catechins, derivatives of coumarins, saponins, and alkaloids).

Table 1 - Phytochemical screening and phenolic compounds content in the aqueous and ethanolic extracts of Achyrocline satureioides.

\begin{tabular}{ccc}
\hline & Phytochemical screening & \\
\hline Chemical constituents & Aqueous extract & Ethanolic extract \\
\hline Organic acids & $(-)$ & $(-)$ \\
Tannins & $(-)$ & $(-)$ \\
Catechins & $(-)$ & $(+)$ \\
Flavonoids & $(+)$ & $(+)$
\end{tabular}

Continues 


\section{Continuation}

\begin{tabular}{|c|c|c|}
\hline Cardiac glycosides & $(-)$ & $(-)$ \\
\hline Carotenoids & $(-)$ & $(-)$ \\
\hline Lactones & $(-)$ & $(-)$ \\
\hline Steroids and triterpenes & $(-)$ & $(-)$ \\
\hline Depsides and depsidones & $(+)$ & $(-)$ \\
\hline Coumarin derivatives & $(-)$ & $(+)$ \\
\hline Saponins & $(-)$ & $(+)$ \\
\hline Alkaloids & $(-)$ & $(+)$ \\
\hline \multicolumn{3}{|c|}{ Phenolic compounds identified by HPLC } \\
\hline $\begin{array}{l}\text { Phenolic compounds } \\
\left(\mathrm{mg} \mathrm{100g}^{-1}\right)\end{array}$ & Aqueous extract & Ethanolic extract \\
\hline Gallic acid & $14.05 \pm 0.11$ & $0.98 \pm 0.03$ \\
\hline Catechin & $75.98 \pm 0.90$ & $53.90 \pm 0.27$ \\
\hline Epigallocatechin gallate & $577.06 \pm 14.89$ & $162.44 \pm 3.59$ \\
\hline Chlorogenic acid & n.i. & $76.48 \pm 1.46$ \\
\hline Caffeic acid & $53.14 \pm 2.05$ & $121.41 \pm 1.99$ \\
\hline Syringic acid & $5.54 \pm 0.11$ & $4.75 \pm 0.71$ \\
\hline p-Coumaric acid & $34.92 \pm 1.41$ & $0.95 \pm 0.01$ \\
\hline Salicylic acid & $1,370.40 \pm 12.02$ & $139.82 \pm 1.69$ \\
\hline Quercetin & $0.08 \pm 0.00$ & $0.26 \pm 0.00$ \\
\hline$\sum$ Phenolic compounds & $2,131.17$ & 560.99 \\
\hline
\end{tabular}

Caption: the signs indicate the presence (+) or the absence (-) of the metabolite. The results correspond to the means of triplicates and the calculated standard deviations. n.i.: not identified.

Source: the authors.

The aqueous extract had a greater content of salicylic acid, followed by epigallocatechin gallate and catechin. On the other hand, the ethanolic extract had a higher content of epigallocatechin gallate, followed by salicylic acid and caffeic acid (Table 1). Salgueiro et al. ${ }^{(17)}$ identified the phenolic compounds isoquercitrin, quercetin, and caffeic acid as the major phenolic compounds present in the aqueous extract of $A$. satureioides. The plant was collected in the Brazilian Pampa biome on the Brazil-Uruguay-Argentina border.

Due to their antioxidant properties, phenolic compounds have played an essential role in protecting against cancer, diabetes, and degenerative diseases, and reducing the risk of gastrointestinal and cardiovascular diseases. ${ }^{(19-20)}$ These compounds have also been investigated as powerful enzyme inhibitors on the toxic and/or pharmacological effects induced by snake venoms. ${ }^{(21-22)}$

Among the phenolic compounds, flavonoids have a high medical-scientific interest because of their anti-inflammatory and hypocholesterolemic properties. Thus, they have the ability to inhibit specific enzymes, stimulate certain hormones and neurotransmitters, and attack free radicals. ${ }^{(23)}$

The flavonoid epigallocatechin gallate is able to inhibit enzymatic activities and signal transduction pathways that have important roles in inflammation and the destruction of joints in arthritis. ${ }^{(24)}$ Quercetin and catechin have anti-inflammatory and anti-thrombogenic properties. The interaction with different enzymatic systems, elimination of free radicals, and inhibition of the arachidonic acid metabolism are the main anti-inflammatory effects 
of flavonoids. ${ }^{(25)}$ Regarding the anti-thrombogenic effects, the flavonoids act inserting themselves in the active site of the thrombin and blocking its activity. ${ }^{(26)}$

\section{Phospholipase and hemolytic activity}

The phospholipase activity (\%) induced by B. atrox (A), B. jararacussu (B), and B. moojeni (C) venoms previously incubated with the aqueous and ethanolic extracts of $A$. satureioides is shown in Figure 1. The aqueous extract, in the lowest ratios (1: $0.1,1: 0.5$, and $1: 1, \mathrm{w}: \mathrm{w})$, increased the phospholipase activity (between 8 and 25\%) induced by the $B$. atrox venom. However, in the highest ratios (1:10 and $1: 20)$, it inhibited $13 \%$ of the activity induced by this venom. The ethanolic extract increased the effect of the same venom in $6.5 \%, 25 \%$, and $12.5 \%$ when evaluated in the ratios of $1: 0.5$, 1:1, and 1:2.5 (w:w), respectively (Figure 1A).

For the phospholipase activity induced by the $B$. jararacussu venom, the aqueous extract of $A$. satureioides presented significant inhibition (7\%) only in the ratio of 1:0.5 (w:w). However, the ethanolic extract increased the activity of this venom by $7 \%$ in the ratio of $1: 20$ (Figure 1B).

Significant inhibitions (6\% and 12\%) were observed to the $B$. moojeni venom after incubation with the aqueous extract in the ratios of 1:10 and 1:20 (w:w), respectively. However, the ethanolic extract increased the activity of this venom by $6 \%$ in all ratios evaluated (Figure 1C).

Figure 1 - Phospholipase activity (\%) induced by Bothrops atrox (A), Bothrops jararacussu (B), and Bothrops moojeni (C) venoms, previously incubated with the aqueous and ethanolic extracts of Achyrocline satureioides.
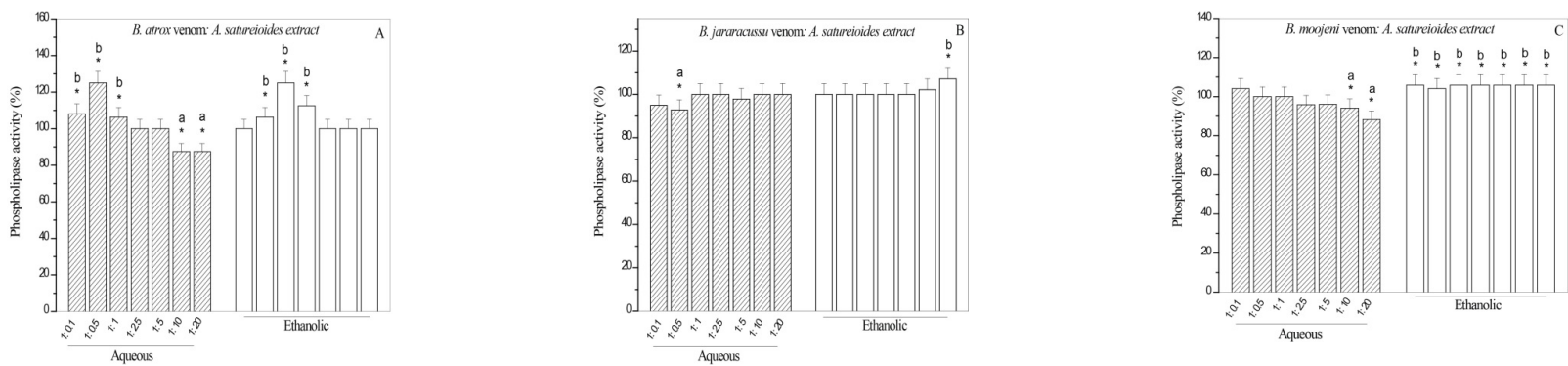

Caption: controls $(+)$ containing only the venoms $(30 \mu \mathrm{g})$ were considered as $100 \%$ activity. The results correspond to the means of the triplicates obtained to each ratio (venom:extract, w:w) and their standard deviations. * Statistically different from its respective positive control by the Tukey's test $(\mathrm{p}<0.05)$. a. Inhibitory effect on the venom activity. b. Potentiating effect on the venom activity.

Source: the authors.

Phospholipases $\mathrm{A}_{2}$ are considered important regulators of the arachidonic acid pathway through which pro-inflammatory mediators such as prostaglandins, leukotrienes, and thromboxanes are released. They are responsible for triggering inflammatory processes and changes in hemostasis and are involved in several diseases such as cancer, ${ }^{(27)}$ atherosclerosis, ${ }^{(28)}$ and neurodegenerative diseases. ${ }^{(29)}$

Several plant extracts have already been described to have inhibitory activity on phospholipases. $^{(21)}$ Groups of isolated metabolites have also been studied and showed powerful inhibitions of phospholipases (e.g., tannins, ${ }^{(30)}$ alkaloids, ${ }^{(31)}$ and flavonoids $\left.{ }^{(32)}\right)$. According to Moura et al. ${ }^{(30)}$ tannins can form complexes with calcium, which is a cofactor of phospholipases $A_{2}$ and various enzymes involved in the coagulation cascade. On the other hand, flavonoids have the ability to bind to the amide groups of different proteins by strong hydrogen bonds. ${ }^{(33)}$

In this context, the inhibition of phospholipases $\mathrm{A}_{2}$ by natural compounds has great scientific 
importance since it allows to prospect mechanisms of action of plant molecules present in therapeutic formulations.

The cytotoxicity test on human erythrocytes was performed with the extracts, and no induction of hemolysis was detected under the conditions evaluated. Subsequently, changes in the hemolytic activity induced by snake venoms were observed (Figure 2).

The aqueous extract of $A$. satureioides increased the hemolysis induced by the venom of $B$. jararacussu by $67 \%$ when evaluated in a ratio of $1: 0.5(\mathrm{w}: \mathrm{w})$ and by $75 \%$ in the ratios of $1: 1$ and $1: 2.5$ (w:w). However, this activity was partially inhibited (18\%) when evaluated in the ratio of $1: 5$ (w:w). Although significant changes in the activity of the venom in the presence of the aqueous extract were observed, the ethanolic extract had a greater modulatory potential on the hemolytic action induced by this venom, inhibiting $100 \%$ of its activity in all ratios analyzed (Figure 2A).

We can suggest that the observed results are due to the interactions between certain plant compounds with some classes of enzymes present in the venoms, which causes fluctuations. Those fluctuations between inhibition and increase of activity, upon dose changes, were observed in all repetitions in the tests (performed in triplicates). Considering the mechanisms of interaction between plant compounds and enzymes described in the literature (e.g., weak, transient, and reversible interactions), it is possible to suggest that the molecules are constantly bonding and breaking down in the aqueous environment. Furthermore, small variations in temperature, agitation, or the number of molecules result in what was observed in the study.

Previous incubation of the aqueous extract with the $B$. moojeni venom resulted in inhibition of approximately $100 \%$ in all the ratios between $1: 0.05$ and $1: 2.5(\mathrm{w}: \mathrm{w})$ and $50 \%$ in a ratio of $1: 5$ (w:w). However, its ethanolic extract exerted significant inhibitions of $25 \%, 27 \%, 29 \%$, and $31 \%$ in the ratios of 1:0.05, 1:0.1, 1:0.5, 1:1 (w:w), respectively, and $100 \%$ in proportions of $1: 2.5$ and $1: 5$ (w:w) (Figure 2B).

For the venom of $C$. durissus terrificus, the aqueous extract enhanced the venom-induced hemolytic activity at the lowest ratios (1:0.05 and $1: 0.1$; w:w) by $88 \%$ but exerted $100 \%$ inhibition in the ratios of 1:1, 1:2.5, and 1:5 (w:w). On the other hand, the ethanolic extract induced inhibitions close to $100 \%$ in all proportions evaluated (Figure 2C).

Figure 2 - Hemolytic activity (\%) induced by Bothrops jararacussu (A), Bothrops moojeni (B), and Crotalus durissus terrificus $(\mathrm{C})$ venoms, previously incubated with the aqueous and ethanolic extracts of Achyrocline satureioides.
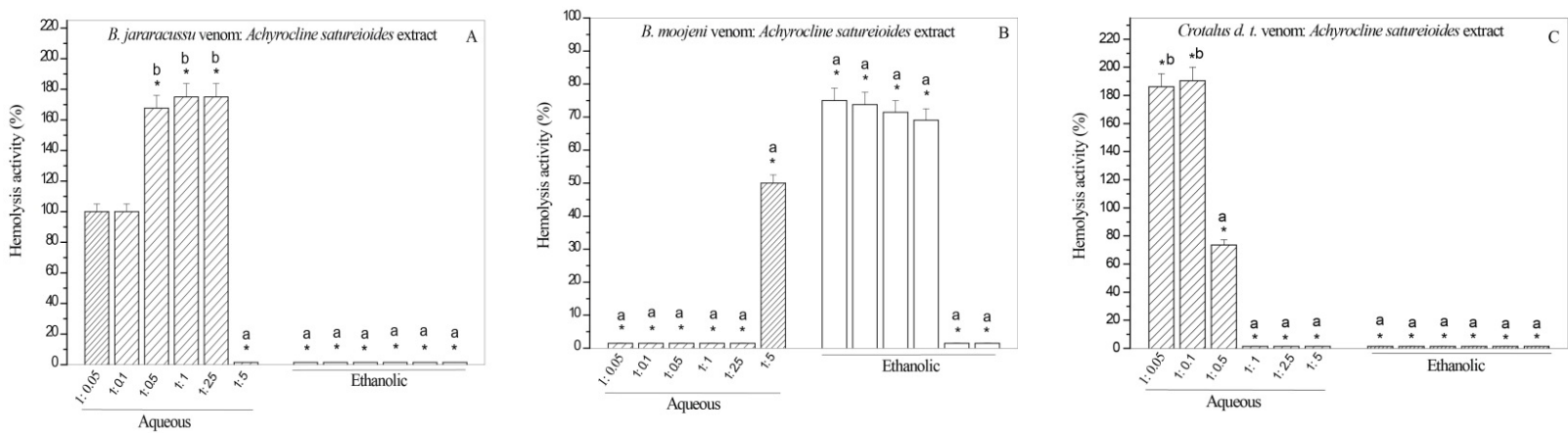

Caption: controls $(+)$ containing only the venoms $(50 \mu \mathrm{g})$ were considered as $100 \%$ activity. The results correspond to the means of the triplicates obtained to each ratio (venom:extract, w:w) and their standard deviations. * Statistically different from its respective positive control by the Tukey's test $(\mathrm{p}<0.05)$. a. Inhibitory effect on the venom activity. b. Potentiating effect on the venom activity.

Source: the authors. 
The enzymes involved in the hemolytic activity are the phospholipases $\mathrm{A}_{2}$, serine proteases, and metalloproteases. These enzymes destabilizes the membrane structure and modify the flow of ions and the intracellular metabolism, causing the rupture of the erythrocytes. ${ }^{(34)}$ Therefore, the inhibition of the hemolytic activity is another evidence of the extract's potential to act on the inflammatory response and the blood coagulation cascade.

The inhibition of the hemolysis by Achyrocline satureioides extracts can be exerted by different compounds present in this plant, which can act in synergism and through different mechanisms. Considering the mechanisms described in the literature, we can suggest the following: the formation of complexes with ions such as $\mathrm{Zn}^{2+}$ and $\mathrm{Ca}^{2+}$ that act as cofactors for several enzyme classes; the direct binding of the compounds to the catalytic site or other regions of the enzymes impeding the binding to the cofactor. ${ }^{(35)}$

\section{Thrombolytic activity}

The thrombolytic activity induced by snake venoms of the species B. moojeni and Lachesis muta muta, previously incubated with the extracts of A. satureioides, is shown in Figure 3. The $A$. satureioides aqueous extract promotes inhibitions of $37 \%$ and $47 \%$, at the ratios of $1: 2.5$ and $1: 5$ (w:w), respectively, on the activity induced by $B$. moojeni venom. However, the ethanolic extract increased the thrombolytic activity by $46 \%$ and $65 \%$ for the ratios of 1:2.5 and 1:5 (w:w), respectively (Figure 3A).

The aqueous extract significantly inhibited thrombi lysis induced by the L. muta muta venom in $41 \%$ and $54 \%$ at the ratios of $1: 2.5$ and $1: 5$ (w:w), respectively. The highest concentrations were responsible for the most significant inhibitions, possibly due to the concomitant increase in the concentration of the phenolic compounds present in the extract. On the other hand, the ethanolic extract significantly enhanced the thrombolytic activity induced by the same venom in the lowest evaluated ratios, thus demonstrating modulating action on proteases present in this venom (view Figure 3B).

Figure 3 - Thrombolytic activity (\%) induced by Bothrops moojeni (A) and Lachesis muta muta (B) venoms, previously incubated with the aqueous and ethanolic extracts of Achyrocline satureioides.
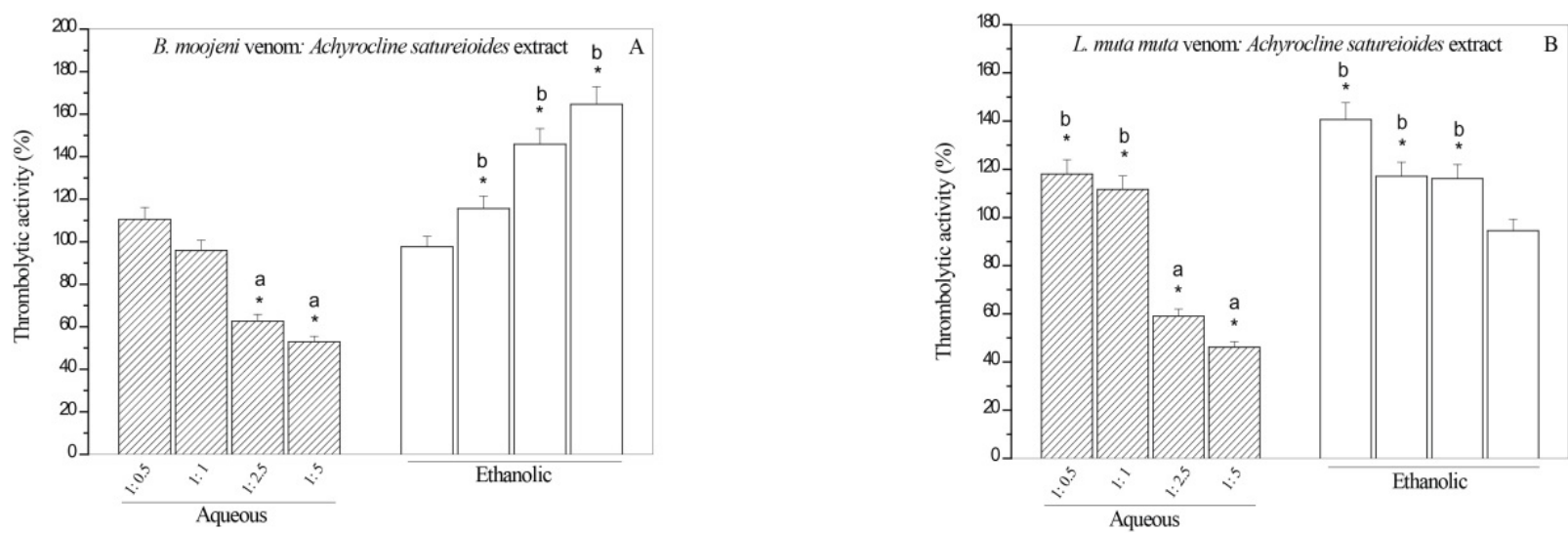

Caption: controls $(+)$ containing only the venoms $(40 \mu \mathrm{g})$ were considered as $100 \%$ activity. The results correspond to the means of the triplicates obtained to each ratio (venom:extract, w:w) and their standard deviations. * Statistically different from its respective positive control by the Tukey's test $(\mathrm{p}<0.05)$. a. Inhibitory effect on the venom activity. b. Potentiating effect on the venom activity.

Source: the authors. 
Thrombosis is related to the imbalance between fibrin formation and fibrinolysis and is the main responsible for the high rate of morbidity and mortality. Thus, it is necessary to evaluate natural compounds that act in inhibiting the enzymes, such as thrombin and phospholipases $\mathrm{A}_{2}$, whose enzymatic activity can generate lyso-PAF (platelet aggregating factor) by the lipoxygenase pathway. Since proteases in snake venom can break coagulation factors or exert thrombin-simile function, they present high homology with human enzymes. ${ }^{(36)}$ Therefore, their inhibition by natural compounds can simulate the anticoagulant and antithrombotic effects on animals.

Elumalai et al. ${ }^{(37)}$ described the induction of thrombolytic activity by the methanolic extract of Bougainvillea glabra. According to these researchers, the metabolites of the tannins, flavonoids, saponins, glycosides, and terpenes groups may be related to thrombi dissolution. In the same context, the flavonoids present in the methanolic extract of Laguncularia racemosa L. were evaluated by Rodrigues et al. ${ }^{(38)}$ as inhibitors of thrombin and acting as natural anticoagulants or thrombolytics.

\section{Coagulant activity}

The citrated plasma coagulation test was performed using pre-determined minimum coagulant doses (MCD) of $5 \mu \mathrm{g}$ and $10 \mu \mathrm{g}$ for B. moojeni and L. muta muta venoms, respectively.

The aqueous extract of $A$. satureioides increased the coagulation time induced by Bothrops moojeni venom in all ratios analyzed $(\mathrm{w}: \mathrm{w}): 1: 0.5$ (23 seconds), 1:1 (54 seconds), 1:2.5 (53 seconds), 1:5 (61 seconds), and 1:10 (100 seconds). The ethanolic extract also increased the coagulation time, but with less effectiveness ( 52 seconds in the ratio of $1: 10)$.

For the L. muta muta venom, the aqueous extract induced an increase in coagulation time (32 seconds to 101 seconds higher than the control), characterizing anticoagulant activity in the ratios of $1: 1,1: 2.5,1: 5$, and 1:10 (w:w). However, the ethanolic extract presented lower anticoagulant action than the aqueous extract and few variations between the analyzed ratios, observing times 12 seconds to 27 seconds higher than the control (Table 2).

Table 2 - Effect of the aqueous and ethanolic extracts of Achyrocline satureioides on the coagulant activity induced by Bothrops moojeni and Lachesis muta muta venoms on citrated human plasma.

\begin{tabular}{cccc}
\hline \multirow{2}{*}{$\begin{array}{c}\text { Achyrocline satureioides } \\
\text { extract }\end{array}$} & $\begin{array}{c}\text { Proportion } \\
\text { venom:extract (w:w) }\end{array}$ & Cothrops moojeni & Lachesis muta muta \\
\cline { 2 - 4 } & $1: 0.5$ & $93.33 \pm 2.08^{\mathrm{a}}$ & $103.00 \pm 5.57$ \\
& $1: 1$ & $124.00 \pm 5.29^{\mathrm{a}}$ & $128.00 \pm 4.36^{\mathrm{a}}$ \\
Aqueous & $1: 2.5$ & $123.00 \pm 4.36^{\mathrm{a}}$ & $147.67 \pm 7.37^{\mathrm{a}}$ \\
& $1: 5$ & $131.33 \pm 5.13^{\mathrm{a}}$ & $173.33 \pm 6.11^{\mathrm{a}}$ \\
& $1: 10$ & $170.00 \pm 5.20^{\mathrm{a}}$ & $197.00 \pm 7.37^{\mathrm{a}}$ \\
\hline \multirow{2}{*}{ Ethanolic } & $1: 0.5$ & $73.33 \pm 5.77$ & $108.67 \pm 7.09^{\mathrm{a}}$ \\
& $1: 1$ & $84.00 \pm 5.29^{\mathrm{a}}$ & $119.33 \pm 8.62^{\mathrm{a}}$ \\
& $1: 2.5$ & $98.00 \pm 3.00^{\mathrm{a}}$ & $133.00 \pm 2.08^{\mathrm{a}}$ \\
& $1: 5$ & $116.00 \pm 4.58^{\mathrm{a}}$ & $124.67 \pm 4.04^{\mathrm{a}}$ \\
& $1: 10$ & $122.33 \pm 5.86^{\mathrm{a}}$ & $123.33 \pm 3.06^{\mathrm{a}}$ \\
\hline
\end{tabular}

Caption: $* 5 \mu \mathrm{g}$ of the evaluated venom. $* * 10 \mu \mathrm{g}$ of the evaluated venom. The results are presented as the average of triplicates \pm standard deviation. ${ }^{\text {a }}$ Differs from their respective positive controls in values equal to or greater than 10 seconds.

Source: the authors. 
Blood coagulation depends, among other steps, on the conversion of fibrinogen to fibrin molecules by the action of thrombin, a serine protease with an essential role in hemostasis. Several cardiovascular illnesses, such as stroke, atherosclerosis, and thrombosis, are linked to dysfunctions in the systems that regulate thrombin production and activity. ${ }^{(39)}$

Mack-Wen et al. ${ }^{(40)}$ demonstrated the anticoagulant action of Brownea ariza ethanolic extract on the activity induced by Bothrops asper venom, indicating a possible inhibitory action on venom proteinases that are capable of activating some factors of the coagulation cascade and converting fibrinogen into fibrin.

In the present study, in addition to the inhibitory action exerted by extracts of $A$. satureioides on coagulant enzymes, we must also consider the effect of flavonoids present in the extracts. They are associated with an increase in coagulation time (Table 2) and the dissolution of thrombi (Figure $3)$. According to Murphy et al. ${ }^{(41)}$ epicatechin increased nitric oxide synthesis in endothelial cells and platelets, which cause vasodilation and inhibition of platelet aggregation.

In this context, extracts of $A$. satureioides present therapeutic potential as anticoagulant agents with possible future applications in the treatment of cardiovascular diseases. However, further studies are necessary to evaluate their effective doses and formulations for use.

\section{Comet assay}

The result of the fragmentation of DNA molecules by the comet assay is shown in Table 3. The aqueous extract of $A$. satureioides, when incubated with the L. muta muta venom in the ratios of 1:0.5 and 1:1 (w:w), presented values of arbitrary units (A.U.) of 71.9 and 65.6, respectively. These are approximately 3 times lower than the value obtained (232.7) for the positive control (L. muta muta venom). A similar result was observed in the ethanolic extract, which presented A.U. of 53.6 and 52.6 in the ratios of 1:0.5 and 1:1 (w:w), respectively. Both extracts inhibited the genotoxic effect induced by the L. muta muta venom, resulting in values of arbitrary units statistically equal to the negative control.

In the negative control, the absence of nucleoids with high damage (class 3 ) and totally damaged DNA (class 4) was observed, as well as in the treatments containing L. muta muta venom previously incubated with the aqueous and ethanolic extracts in the ratios of 1:0.5 and 1:1 (w:w) (Table 3). Controls using only the extracts $\left(250 \mu \mathrm{g} \mathrm{mL}^{-1}\right.$ and $50 \mu \mathrm{g} \mathrm{mL}^{-1}$ ) were also performed, and the values of arbitrary units were similar to the negative control (data not shown).

Table 3 - Effect of the aqueous and ethanolic extracts of Achyrocline satureioides on the genotoxic activity induced by the Lachesis muta muta venom evaluated by the comet assay. The average percentage of nucleoids was classified according to the levels of DNA fragmentation and arbitrary units.

\section{Nucleoids (\%)}

\begin{tabular}{|c|c|c|c|c|c|c|}
\hline \multirow{2}{*}{ Treatments } & \multicolumn{5}{|c|}{ Comet classes (damage \%) } & \multirow{2}{*}{$\begin{array}{c}\text { Arbitrary } \\
\text { units (A.U.) }\end{array}$} \\
\hline & $\mathbf{0}(\leq 5)$ & $1(5-20)$ & $2(20-40)$ & $3(40-85)$ & $4(\geq 85)$ & \\
\hline$C(-)$ & $49.9 \pm 5.4 \mathrm{a}$ & $48.0 \pm 7.1 \mathrm{a}$ & $2.1 \pm 0.8 b$ & $0.0 \pm 0.0 \mathrm{c}$ & $0.0 \pm 0.0 \mathrm{~b}$ & $52.2 \pm 3.7 \mathrm{c}$ \\
\hline $\mathrm{C}(+)^{*}$ & $2.1 \pm 0.8 \mathrm{c}$ & $12.8 \pm 6.2 \mathrm{c}$ & $44.3 \pm 5.4 \mathrm{a}$ & $31.9 \pm 7.3 \mathrm{a}$ & $8.9 \pm 4.7 \mathrm{a}$ & $232.7 \pm 23.2 \mathrm{a}$ \\
\hline $\mathrm{C}(+) * *$ & $10.1 \pm 4.4 \mathrm{c}$ & $31.0 \pm 0.7 \mathrm{~b}$ & $39.6 \pm 6.1 \mathrm{a}$ & $12.6 \pm 2.9 \mathrm{~b}$ & $6.7 \pm 0.7 \mathrm{a}$ & $174.8 \pm 7.5 b$ \\
\hline
\end{tabular}

Continues 


\section{Continuation}

Venom:extract (w:w)

\begin{tabular}{cccccccc}
\hline \multirow{2}{*}{ Aqueous } & $(1: 0.5)$ & $37.6 \pm 0.9 \mathrm{~b}$ & $52.9 \pm 3.9 \mathrm{a}$ & $9.5 \pm 3.7 \mathrm{~b}$ & $0.0 \pm 0.0 \mathrm{c}$ & $0.0 \pm 0.0 \mathrm{~b}$ & $71.9 \pm 3.5 \mathrm{c}$ \\
& $(1: 1)$ & $44.1 \pm 1.8 \mathrm{ab}$ & $46.2 \pm 2.8 \mathrm{a}$ & $9.7 \pm 1.0 \mathrm{~b}$ & $0.0 \pm 0.0 \mathrm{c}$ & $0.0 \pm 0.0 \mathrm{~b}$ & $65.6 \pm 0.8 \mathrm{c}$ \\
\hline \multirow{2}{*}{ Ethanolic } & $(1: 0.5)$ & $50.6 \pm 2.0 \mathrm{a}$ & $45.2 \pm 0.8 \mathrm{a}$ & $4.2 \pm 1.2 \mathrm{~b}$ & $0.0 \pm 0.0 \mathrm{c}$ & $0.0 \pm 0.0 \mathrm{~b}$ & $53.6 \pm 3.2 \mathrm{c}$ \\
& $(1: 1)$ & $51.4 \pm 1.7 \mathrm{a}$ & $44.6 \pm 0.3 \mathrm{a}$ & $4.0 \pm 1.3 \mathrm{~b}$ & $0.0 \pm 0.0 \mathrm{c}$ & $0.0 \pm 0.0 \mathrm{~b}$ & $52.6 \pm 3.0 \mathrm{c}$
\end{tabular}

Caption: C (-): blood. C (+)*: Lachesis muta muta venom $\left(50 \mu \mathrm{g} \mathrm{mL}^{-1}\right) . \mathrm{C}(+)^{* *}$ : doxorubicin $\left(100 \mu \mathrm{g} \mathrm{mL}^{-1}\right)-$ genotoxic antitumor drug. The values represent the average of 3 tests performed with blood from different volunteers, with 300 nucleoids per treatment/volunteer/test, counting a total of 900 nucleoids/treatment. Values followed by the same letter in the columns do not differ from each other by the Tukey's test $(p<0.05)$.

Source: the authors.

The comet assay has been widely used and complement the toxicological characterization of natural compounds to investigate the genotoxic and/or antigenotoxic effects. Simão et al. ${ }^{(42)}$ found that the aqueous extract of leaves of Pereskia grandifolia at different doses, higher than the one recommended for consumption, did not induce genotoxic effects. Salgueiro et al. ${ }^{(17)}$ investigated the aqueous extract of $A$. satureioides on human leukocytes and described in their results the predominance of low DNA damage levels at doses of 30, 60,150 , and $300 \mu \mathrm{g}$.

Cesar et al. ${ }^{(43)}$ demonstrated the absence of DNA fragmentation in human leukocytes, using the aqueous extracts of different cultivars from Psidium guajava, even when evaluated at a high concentration $\left(300 \mu \mathrm{L} \mathrm{mL}^{-1}\right)$. In addition, nucleoids treated with these extracts decreased by $75 \%$ the frequency of DNA damage (induced by doxorubicin), demonstrating their antigenotoxic potential. The toxicological characterization of the secondary metabolites contained in plant extracts is required since they might have harmful or therapeutic effects, depending on parameters such as dosage and chronic usage.

\section{Inhibition of digestive enzymes}

The results of the enzymatic inhibition exerted by the aqueous and ethanolic extracts of $A$. satureioides before and after exposure to simulated gastric fluid are presented in Table 4.

Table 4 - Inhibition of digestive enzymes exerted by the aqueous and ethanolic extracts of Achyrocline satureioides before and after exposure to simulated gastric fluid.

\begin{tabular}{|c|c|c|c|c|c|c|c|c|}
\hline \multirow{3}{*}{ Enzyme } & \multicolumn{4}{|c|}{ Aqueous extract } & \multicolumn{4}{|c|}{ Ethanolic extract } \\
\hline & \multicolumn{2}{|c|}{$\begin{array}{c}\text { Inhibition } \\
\text { before exposure }\end{array}$} & \multicolumn{2}{|c|}{$\begin{array}{c}\text { Inhibition } \\
\text { after exposure }\end{array}$} & \multicolumn{2}{|c|}{$\begin{array}{c}\text { Inhibition } \\
\text { before exposure }\end{array}$} & \multicolumn{2}{|c|}{$\begin{array}{c}\text { Inhibition } \\
\text { after exposure }\end{array}$} \\
\hline & $(\mathrm{IEU})^{\mathrm{a}}$ & $(\%)$ & $(I E U)^{\mathrm{a}}$ & $(\%)$ & $(\mathbf{I E U})^{\mathrm{a}}$ & $(\%)$ & $(\mathbf{I E U})^{\mathrm{a}}$ & $(\%)$ \\
\hline Amylase & ns & 19.35 & nd & nd & $75.42 \pm 4.3$ & 43.23 & $62.54 \pm 3.1$ & 34.53 \\
\hline Glycosidase & $3.20 \pm 0.2$ & 57.51 & $1.91 \pm 0.2$ & 40.49 & $1.28 \pm 0.1$ & 41.50 & $0.48 \pm 0.0$ & 17.31 \\
\hline Lipase & $10.42 \pm 0.2$ & 49.03 & $6.32 \pm 0.3$ & 29.93 & ns & 32.62 & nd & nd \\
\hline Trypsin & $3.86 \pm 0.1$ & 67.04 & $3.77 \pm 0.2$ & 48.72 & $2.05 \pm 0.1$ & 55.76 & $1.05 \pm 0.0$ & 27.16 \\
\hline
\end{tabular}

Caption: data from five repetitions, with mean \pm standard deviation. ${ }^{a}$ The Achyrocline satureioides extract measured for each of the enzymes was diluted to provide an inhibition between $40 \%$ and $80 \%$ and ensure result reliability. IEU: Inhibited Enzyme Unit in $\mu \mathrm{mol} \mathrm{min} \mathrm{g}^{-1}$ sample (extract). nd: inhibition not determined. ns: inhibition not significant. Source: the authors. 
The aqueous extract of $A$. satureioides did not inhibit the $\alpha$-amylase activity, as previously described for other plant species such as Melissa officinalis L., Passiflora incarnata L., Valeriana officinalis L., and Matricaria chamomilla L. ${ }^{(44)}$ The ethanolic extract inhibited $75.42 \mu \mathrm{mol} \mathrm{min} \mathrm{m}^{-1} \mathrm{~g}^{-1}$, equivalent to a percentage of $43.23 \%$. However, following the exposure to gastric fluid, inhibition decreased by $17.1 \%$. Marques et al., ${ }^{(6)}$ when studying the methanolic extract of the Malpighia emarginata bagasse flour, detected inhibition of 238.96 $\mu \mathrm{mol} \mathrm{min}^{-1} \mathrm{~g}^{-1}$. Simão et al. ${ }^{(45)}$ verified that the extracts of the cultivars Paluma, Pedro Sato, and Seculo XXI from Psidium guajava showed inhibition of 13,776.93, 13,130.47, and 14,410.60 $\mu \mathrm{mol}$ $\min ^{-1} \mathrm{~g}^{-1}$, respectively, which are results higher than the one found in this study. This may be due to differences in the types and amounts of compounds found in each evaluated extract. The inhibition of $\alpha$-amylase, an enzyme involved in carbohydrate digestion, might be an additional therapy to the early treatment of type 2 diabetes since it decreases postprandial hyperglycemia and suppresses glucose production and/or uptake from the gastrointestinal tract. ${ }^{(46)}$

The aqueous and ethanolic extracts of $A$. satureioides showed inhibition of the $\alpha$-glycosidase activity of 3.20 and $1.28 \mu \mathrm{mol} \mathrm{min} \mathrm{m}^{-1} \mathrm{~g}^{-1}$, respectively, corresponding to $57.51 \%$ and $41.50 \%$. The inhibitory potential of these extracts was superior to the one found by Simão et al., ${ }^{(12)}$ who reported for the aqueous extracts of Aloe vera (L.) Burm and Baccharis trimera (Less.) DC inhibitions of 1.23 and $0.58 \mu \mathrm{mol} \mathrm{min} \mathrm{m}^{-1} \mathrm{~g}^{-1}$, respectively. The use of medicinal plants as inhibitors of enzymes involved in glucose metabolism has become a promising alternative to the treatment of obesity-associated diseases, especially the ones regarding the incidence of type 2 diabetes. These inhibitors induce carbohydrate tolerance, satiety, weight loss, delay of emptying, and reduce the release of glucose into the blood. ${ }^{(46)}$

Inhibition of lipases, which results in a delay in the hydrolysis process of triglycerides, was detected only for the aqueous extract of $A$. satureioides whose inhibition was $10.42 \mu \mathrm{mol}$ $\min ^{-1} \mathrm{~g}^{-1}(49.03 \%)$. This inhibition may be associated with the content of phenolic compounds present in the aqueous extract, which were 3.8 times higher than the content of ethanolic extract (Table 1). According to Lunagariya et al., ${ }^{(47)}$ some amino acids present at the lipase catalytic site may interact with the phenolic compounds, forming stable complexes and reducing the structural flexibility of the enzyme. This makes it insoluble in the reactional environment and, therefore, inactive. ${ }^{(14)}$

The aqueous extract of $A$. satureioides inhibited $3.86 \mu \mathrm{mol} \mathrm{min} \mathrm{m}^{-1} \mathrm{~g}^{-1}$ in trypsin activity prior to the exposure to simulated gastric fluid, exhibiting $67.04 \%$ inhibition. However, after exposure to simulated gastric fluid, inhibition was $48.72 \%$. The ethanol extract had an inhibition of $2.05 \mu \mathrm{mol}$ $\min ^{-1} \mathrm{~g}^{-1}$, whose percentage was $55.76 \%$. After the exposure to simulated gastric fluid, it reduced to $27.16 \%$.

Proteases play an important role in cell metabolism by catalyzing various processes, such as food digestion, tissue remodeling, and host defense against potential pathogens. ${ }^{(48)}$ Trypsin inhibitors have already been considered antinutritional compounds because of their inhibitory activity on human and animal enzymes. Also, they can cause gastric problems and lead to pancreatic hypertrophy or hyperplasia. ${ }^{(49)}$ Hence, an advantage is attributed to the decrease in trypsin inhibition after exposure to gastric fluid because protein digestibility is little affected.

The presence of different levels of phenolic compounds in the aqueous and ethanolic extracts of $A$. satureioides (Table 1 ) is probably responsible for the various inhibitory profiles observed in the digestive enzyme assays. The aqueous extract had a higher catechin and epigallocatechin gallate content, exerting greater inhibition on $\alpha$-glycosidase and lipase activity. Similarly, Koh et al. ${ }^{(50)}$ observed that the inhibitory profile of different teas on $\alpha$-amylase and $\alpha$-glycosidase enzymes were correlated with high catechin content. 
Phenolic compounds such as caffeic acid, chlorogenic acid, catechin, epigallocatechin gallate, and quercetin have already been described as having a thermogenic effect, ability to oxidize fats, control appetite, regulate obesity-related hormone levels, and inhibit digestive enzymes involved in the absorption of carbohydrates and lipids. ${ }^{(45,51)}$ Therefore, the synergy between the phenolic compounds present in A. satureioides extracts should be considered to better understand the inhibitory action of the extracts on the digestive enzymes.

\section{Conclusion}

The aqueous and ethanolic extracts of $A$. satureioides showed effects (inhibition or potentiation) on the biological activities induced by different snake venoms, highlighting their antigenotoxic activity and modulatory potential on hemostasis-related processes. This is probably due to the presence of phenolic compounds that interact with catalytic sites of the enzymes or hydrophobic regions present in these molecules. The compounds may also form complexes with ionic cofactors. The inhibitions exerted on digestive enzymes also highlight the potential for future use of these extracts in the prevention and/or treatment of various pathologies, such as thrombosis, obesity, diabetes, and several others with inflammatory origin. However, further research is needed to better understand the mechanisms behind the interactions between the bioactive compounds and enzymes.

\section{Acknowledgements}

The authors are grateful for the financial support of Conselho Nacional de Desenvolvimento Científico e Tecnológico (CNPq), Coordenação de Aperfeiçoamento de Pessoal de Nível Superior (CAPES), and Fundação de Amparo à Pesquisa de Minas Gerais (FAPEMIG), Brazil.

\section{References}

1 Sponchiado G, Adam ML, Silva CD, Soley BS, Mello-Sampayo C, Cabrini DA, et al. Quantitative genotoxicity assays for analysis of medicinal plants: A systematic review. J Ethnopharmacol. 2016;178:289-96. doi: 10.1016/j.jep.2015.10. 026.

2 Shin S, Yi JM, Kim NS, Park CS, Kim SH, Bang OS. Aqueous extract of Forsythia viridissima fruits: Acute oral toxicity and genotoxicity studies. J Ethnopharmacol. 2020;249:112381. doi: 10.1016/j.jep.2019.112381.

3 Berling I, Isbister GK. Hematologic effects and complications of snake envenoming. Transf Med Rev. 2015;29(2):82-9. doi: 10.1016/j.tmrv. 2014.09.005.

4 Retta D, Dellacassa E, Villamil J, Suárez SA, Bandoni AL. Marcela, a promising medicinal and aromatic plant from Latin America: A review. Ind Crops Prod. 2012;38:27-38. doi: 10.1016/j.indcrop.2012.01.006.

5 Matos FJA. Introdução à fitoquímica experimental. 2a ed. Fortaleza (CE): UFC; 1997.

6 Marques TR, Caetano AA, Simão AA, Castro FCO, Ramos VO, Corrêa AD. Metanolic extract of Malpighia emarginata bagasse: phenolic compounds and inhibitory potential on digestive enzymes. Braz J Pharmacog. 2016;26(2):191-6. doi: 10.1016/j.bjp.2015.08.015.

7 Gutiérrez JM, Avila C, Rojas E, Cerdas L. An alternative in vitro method for testing the potency of the polyvalent antivenom produced in Costa Rica. Toxicon. 1988;26(4):411-3. doi: 10.1016/0041-0101(88)90010-4.

8 Cintra AC, Toni LG, Sartim MA, Franco JJ, Caetano RC, Murakami MT, et al. Batroxase, a new metalloproteinase from $B$. atrox snake venom with strong fibrinolytic activity. Toxicon. 2012;60(1):70-82. doi: 10.1016/j.toxicon.2012. 03.018 .

9 Selistre HS, Queiroz LS, Cunha OAB, Souza GEP, Giglio JR. Isolation and characterization of hemorrhagic, myonecrotic and edema-inducing toxins from Bothrops insularis (jararaca ilhoa) 
snake venom. Toxicon. 1990;28(3):261-73. doi: 10.1016/0041-0101(90)90062-C.

10 Nandhakumar S, Parasuraman S, Shanmugam MM, Rao KR, Chand P, Bhat BV. Evaluation of DNA damage using single-cell gel electrophoresis (Comet Assay). J Pharmacol Pharmacother. 2011;2(2):107-11. doi: 10.4103/0976$500 X .81903$.

11 Collins AR, Dusinská M, Franklin M, Somorovská M, Petrovská $\mathrm{H}$, Duthie $\mathrm{S}$, et al. Comet assay in human biomonitoring studies: reliability, validation, and applications. Environ Mol Mutagen. 1997;30(2):139-46. doi: 10.1002/(sici)1098-2280(1997)30:2<139::aidem6>3.0.co;2-i.

12 Simão AA, Corrêa AD, Chagas PMB. Inhibition of digestive enzymes by medicinal plant aqueous extracts used to aid the treatment of obesity. J Med Plants Res. 2012;6(47):582630. doi: 10.5897/JMPR12.1023.

13 Braga MA, Abreu TS, Trento MV, Machado GHA, Pereira LLS, Simão AA, et al. Prospection of enzyme modulators in aqueous and ethanolic extracts of Lippia sidoides leaves: genotoxicity, digestion, inflammation, and hemostasis. Chem Biodivers. 2019;16(3):e1800558. doi: 10.1002/cbdv.201800558.

14 Souza SP, Pereira LLS, Souza AA, dos Santos CD. Inhibition of pancreatic lipase by extracts of Baccharis trimera (Less.) DC., Asteraceae: evaluation of antinutrients and effect on glycosidases. Braz J Pharmacog. 2011;21(3):4505. doi: 10.1590/S0102-695X2011005000049.

15 The United States Pharmacopeia. The national formulary NF 18 (Pharmacopeial Convention Ing). Rockvile; 2005.

16 R Core Team. R: A Language and Environment for Statistical Computing. R Foundation for Statistical Computing. Viena, Austria; 2012.

17 Salgueiro ACF, Folmer V, Rosa HS, Costa MT, Boligon AA, Paula FR, et al. In vitro and in silico antioxidant and toxicological activities of Achyrocline satureioides. J Ethnopharmacol. 2016;194:6-14. doi: 10.1016/j.jep.2016.08.048.
18 Balestrin LA, Fachel FNS, Koester LS, Bassani VL, Teixeira HT. A stability-indicating ultrafast liquid chromatography method for the assay of the main flavonoids of Achyrocline satureioides (Marcela) in porcine skin layers and nanoemulsions. Phytochem Anal. 2020; 31:1-10. doi: 10.1002/pca.2962.

19 Quero J, Mármol I, Cerrada E, RodríguezYoldi MJ. Insight into the potential application of polyphenol-rich dietary intervention in degenerative disease management. Food Funct. 2020;11:2805-25. doi: 10.1039/D0FO00216J.

20 Leuci R, Brunetti L, Poliseno V, Laghezza A, Loiodice F, Tortorella P, et al. Natural compounds for the prevention and treatment of cardiovascular and neurodegenerative diseases. Foods. 2021;10(1):29. doi: 10.3390/foods100 10029.

21 Guimarães CL, Moreira-Dill LS, Fernandes RS, Costa TR, Hage-Melim LI, Marcussi S, et al. Biodiversity as a source of bioactive compounds against snakebites. Curr Med Chem. 2014;21(25):2952-79. doi: 10.2174/09298673 113206660295 .

22 Cesar PHS, Trento MVC, Konig IFM, Marcussi S. Catechin and epicatechin as an adjuvant in the therapy of hemostasis disorders induced by snake venoms. J Biochem Mol Toxicol. 2020; 34:e22604. doi: 10.1002/jbt.22604.

23 Burkard M, Leischner C, Lauer UM, Busch C, Venturelli S, Frank J. Dietary flavonoids and modulation of natural killer cells: implications in malignant and viral diseases. J Nutr Biochem. 2017;46:1-12. doi: 10.1016/j.jnutbio. 2017.01.006.

24 Singh R, Akhtar N, Haqqi TM. Green tea polyphenol epigallocatechin-3-gallate: inflammation and arthritis. Life Sci. 2010;86(25-26): 907-18. doi: 10.1016/j.lfs.2010.04.013.

25 Ciumărnean L, Milaciu MV, Runcan O, Vesa SC, Răchișan AL, Negrean V, et al. The effects of flavonoids in cardiovascular diseases. Molecules. 2020;25(18):4320. doi: 10.3390/ molecules25184320. 
26 Mozzicafreddo M, Cuccioloni M, Eleuteri AM, Fioretti E, Angeletti M. Flavonoids inhibit the amidolytic activity of human thrombin. Biochimie. 2006;88(9):1297-306. doi: 10.1016/j. biochi.2006.04.007.

27 Peng Z, Chang Y, Fan J, Ji W, Su C. Phospholipase $\mathrm{A}_{2}$ superfamily in cancer. Cancer Lett. 2020;497:165-77. doi: 10.1016/j.canlet. 2020.10.021.

28 Yin WG, Zhou P, Zhou XH, Liu YM, Chen C, Xuan SX, et al. An analysis of the correlation between the human apolipoprotein E gene polymorphism and lipoprotein-associated phospholipase $\mathrm{A}_{2}$. Cardiovasc Diagn Ther. 2020;10 (3):520-5. doi: $10.21037 /$ cdt-20-43.

29 Chao H, Liu Y, Fu X, Xu X, Bao Z, Lin C, et $a l$. Lowered iPLA2 $\gamma$ activity causes increased mitochondrial lipid peroxidation and mitochondrial dysfunction in a rotenone-induced model of Parkinson's disease. Exp Neurol. 2018;300:74-86. doi: 10.1016/j.expneurol. 2017.10 .031 .

30 Moura VM, Silva WC, Raposo JD, Freitas-deSousa LA, Santos MC, Oliveira RB, et al. The inhibitory potential of the condensed-tanninrich fraction of Plathymenia reticulata Benth. (Fabaceae) against Bothrops atrox envenomation. J Ethnopharmacol. 2016;183:136-42. doi: 10.1016/j.jep.2016.02.047.

31 Khan MH. Anti-inflammatory potential of alkaloids as a promising therapeutic modality. Lett Drug Des Discov. 2017;14(2):240-9. doi: $10.2174 / 1570180813666160712224752$.

32 Belchor MN, Gaeta HH, Rodrigues CFB, Costa CRC, Toyama DO, Passero LFD, et al. Evaluation of rhamnetin as an inhibitor of the pharmacological effect of secretory phospholipase $A_{2}$. Molecules. 2017;22(9):1441. doi: 10.3390/molecules22091441.

33 Mors WB, Nascimento MC, Pereira BM, Pereira NA. Plant natural products active against snake bite - the molecular approach. Phytochemistry. 2000;55(6):627-42. doi: 10.1016/S0031-9422 (00)00229-6.
34 Gutiérrez JM, Lomonte B. Phospholipases $\mathrm{A}_{2}$ : unveiling the secrets of a functionally versatile group of snake venom toxins. Toxicon. 2013; 62:27-39. doi: 10.1016/j.toxicon.2012.09.006.

35 Silva SL, Calgarotto AK, Maso V, Damico DC, Baldasso P, Veber CL, et al. Molecular modeling and inhibition of phospholipase $\mathrm{A}_{2}$ by polyhydroxy phenolic compounds. Eur J Med Chem. 2009;44(1):312-21. doi: 10.1016/j. ejmech.2008.02.043.

36 Kini RM, Koh CY. Metalloproteases affecting blood coagulation, fibrinolysis and platelet aggregation from snake venoms: definition and nomenclature of interaction sites. Toxins. 2016;8(10):1-27. doi: 10.3390/toxins8100284.

37 Elumalai A, Eswariah MC, Chowdary CHV, Kumar R, Anusha M, Naresh K. Screening of thrombolytic activity of Bougainvillea glabra leaves extract by in vitro. Asian J Res Pharm Sci. 2012;2(4):134-6.

38 Rodrigues CF, Gaeta HH, Belchor MN, Ferreira MJ, Pinho MV, Toyama DO, et al. Evaluation of potential thrombin inhibitors from the white Mangrove (Laguncularia racemosa (L.) C.F. Gaertn.). Mar Drugs. 2015;13(7):4505-19. doi: 10.3390/md13074505.

39 Rodriguez BAT, Bhan A, Beswick A, Elwood PC, Niiranen TJ, Salomaa V, et al. A platelet function modulator of thrombin activation is causally linked to cardiovascular disease and affects PAR4 receptor signaling. Am J Hum Genet. 2020;107(2):211-21. doi: 10.1016/j. ajhg.2020.06.008.

40 Mack-Wen GVL, Rico GLB, Alarcón PJC, Pereañez JJA. In vitro inhibition of Bothrops asper venom by ethanol extracts from Brownea ariza B. (Caesalpiniaceae). Vitae. 2011;18(1): 43-8. https://revistas.udea.edu.co/index.php/ vitae/article/view/8776

41 Murphy KJ, Chronopoulos AK, Singh I, Francis MA, Moriarty H, Pike MJ, et al. Dietary flavanols and procyanidin oligomers from cocoa (Theobroma cacao) inhibit platelet function. Am J Clin Nutr. 2003;77(6):1466-73. doi: 10. 1093/ajen/77.6.1466. 
42 Simão AA, Corrêa AD, Carvalho TCL, Cesar PHS, Oliveira CHM, Marcussi S. Pharmacotoxic characterization of the aqueous extract from Pereskia grandifolia leaves. J Med Plants Res. 2015;9(7):216-22. doi: 10.5897/JMPR 2014.5647.

43 Cesar PHS, Trento MVC, Oliveira DA, Simão AA, Vieira LFA, Marcussi S. Prospection of effects of guava leaves infusion: antigenotoxic action and enzymatic inhibition. Nat Prod Commun. 2017;12(6):957-60. doi: 10.1177/ 1934578X1701200631.

44 Herrera T, Aguilera Y, Rebollo-Hernanz M, Bravo E, Beníteza V, Martínez-Sáez N, et al. Teas and herbal infusions as sources of melatonin and other bioactive non-nutrient components. LWT - Food Sci Technol. 2018:89:6573. doi: 10.1016/j.lwt.2017.10.031.

45 Simão AA, Marques TR, Marcussi S, Corrêa AD. Aqueous extract of Psidium guajava leaves: phenolic compounds and inhibitory potential on digestive enzymes. An Acad Bras Ciên. 2017;89(Supl 3):2155-65. doi: 10.1590/ 0001-3765201720160067.

46 Costamagna MS, Zampini IC, Alberto MR, Cuello S, Torres S, Pérez J, et al. Polyphenols rich fraction from Geoffroea decorticans fruits flour affects key enzymes involved in metabolic syndrome, oxidative stress and inflammatory process. Food Chem. 2016;190:392-402. doi: 10.1016/j.foodchem.2015.05.068.

47 Lunagariya NA, Patel NK, Jagtap SC, Bhutani KK. Inhibitors of pancreatic lipase: state of the art clinical perspectives. Excli J. 2014;13:897921. doi: 10.17877/DE290R-6941.

48 Kostekli M, Karakaya S. Protease inhibitors in various flours and breads: Effect of fermentation, baking and in vitro digestion on trypsin and chymotrypsin inhibitory activities. Food Chem. 2017;224:62-8. doi:10.1016/j.foodchem.2016.12.048.

49 McDougall GJ, Shapiro F, Dobson P, Smith P, Blake A, Stewart D. Different polyphenolic components of soft fruits inhibit $\alpha$-amylase and $\alpha$-glucosidase. J Agric Food Chem. 2005; 53(7):2760-6. doi: 10.1021/jf0489926.
50 Koh LW, Wong LL, Loo YY, Kasapis S, Huang D. Evaluation of different teas against starch digestibility by mammalian glycosidases. J Agric Food Chem. 2010;58(1):148-54. doi: 10.1021/jf903011g.

51 Rains TM, Agarwal S, Maki KC. Antiobesity effects of green tea catechins: a mechanistic review. J Nutr Biochem. 2011;22(1):1-7. doi: 10.1016/j.jnutbio.2010.06.006. 